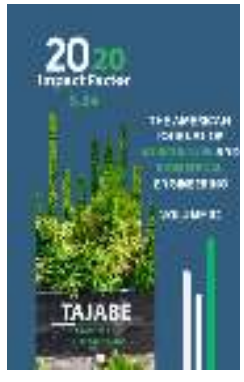

Journal Website: http://usajournalshub.c om/index,php/tajabe

Copyright: Original content from this work may be used under the terms of the creative commons attributes 4.0 licence.

\section{Influence Of Cotton Cultivation Techniques In Bukhara Region On Reduction Of Damage To Plants By Turnip Moth}

\author{
Tukhtaev Shonazar Khojievich \\ PhD In Agricultural Sciences, Bukhara State University, Associate Professor Of Soil Science \\ Department, Uzbekistan
}

\section{Ganieva Feruza Amrilloevna \\ Bukhara State University, Lecturer Of Soil Science Department, Uzbekistan}

Tukhtaeva Feruza

Physiology Of Humans And Animals, Intern, National University Of Uzbekistan Named After Mirzo Ulugbek, Tashkent, Uzbekistan

\title{
ABSTRACT
}

In Jondor region, cotton is damaged by more than 200 types of pests. One of the most common is turnip moth (Agrotis segetum), harmfulness of which reaches up to $18 \%$. To preserve cotton from damage by turnip moth (Agrotis segetum), a complex system of measures is used, among which the leading place as the safest pest control measures is taken by agrotechnical combating methods that include changes of main environmental factors, inhibition of the development of pests and improvement of cotton growing conditions.

\section{KEYWORDS}

Pest, agrotechnical, turnip moth, fall plowing, spring plowing, ketmen (a kind of hand plow), plow, caterpillar, black nightshade, field bindweed, white marsh.

\section{INTRODUCTION}

The task of the research was to study the effect of some agrotechnical techniques on reducing plant damage by turnip moth (Agrotis segetum).

Field experiments were carried out in the farms of Jondor district of Bukhara region in 2018-
2019. In 2020 experiment (in the farm), autumn plowing was carried out on November 30; spring plowing on March 26 with a plow to a depth of $30-35 \mathrm{~cm}$. Both fields were located side by side, 2.5 hectares each Count of the number of caterpillars of turnip moth (Agrotis 
segetum) was carried out according to the F.M. Uspensky method.

As the obtained data show (Table 1), autumn plowing reduced the number of turnip moth caterpillars in cotton by 0.2-1.0 specimen per
$1 \mathrm{~m} 2$ in comparison with spring plowing. This contributed to $1.8 \%$ reduction of turnip moth damage to cotton.

\section{Table 1}

Influence of autumn plowing on the number of turnip moths and damage to cotton (farm) in Jondor district of Bukhara region.

\begin{tabular}{|c|c|c|c|c|c|}
\hline \multirow{2}{*}{ Index } & \multicolumn{5}{|c|}{ Count dates } \\
\hline & May 19 & May 25 & May 30 & June 5 & June 10 \\
\hline \multicolumn{6}{|c|}{ Winter plowing } \\
\hline $\begin{array}{c}\text { number of } \\
\text { caterpillars } \\
\text { spec/m² }\end{array}$ & 0.6 & 1.1 & 1.6 & 1.4 & 1.4 \\
\hline $\begin{array}{c}\text { damaged } \\
\text { plants, \% }\end{array}$ & 0.2 & 1.1 & 1.4 & 3.4 & 3.2 \\
\hline $\begin{array}{l}\text { destroyed } \\
\text { plants, \% }\end{array}$ & 1.3 & 3.9 & 4.8 & 6.1 & 5.0 \\
\hline \multicolumn{6}{|c|}{ Spring plowing } \\
\hline $\begin{array}{c}\text { number of } \\
\text { caterpillars } \\
\text { spec/m² }\end{array}$ & 0.9 & 1.9 & 2.2 & 1.7 & 2.4 \\
\hline $\begin{array}{l}\text { damaged } \\
\text { plants, \% }\end{array}$ & 0,4 & 1.3 & 2.1 & 6,3 & 5.2 \\
\hline $\begin{array}{l}\text { destroyed } \\
\text { plants, \% }\end{array}$ & 1.8 & 6.4 & 12.1 & 12.4 & 11.6 \\
\hline
\end{tabular}

Winter irrigation contributed to a decrease in the number of caterpillars of turnip moth (Agrotis segetum) by 0,3 specimen per $1 \mathrm{~m}^{2}$ as compared to the control figures (Table 2). Because of decrease in the number of caterpillars and better development of plants in areas with winter irrigation, damage to cotton by turnip moth (Agrotis segetum) was reduced by $4.3 \%$. This is because winter watering disrupts normal overwintering conditions of caterpillars, making them freeze or preventing from reaching the surface. At the same time, sufficient moisture in the soil in spring ensures intensive growth of cotton. As a result, plant damage by turnip moth (Agrotis segetum) as well as yield losses are reduced. 
Table 2

Influence of winter irrigation on the number of caterpillars of turnip moth (Agrotis segetum) and damage to cotton seedlings of the farm in Jondor district of Bukhara region,

2019

\begin{tabular}{|c|c|c|c|c|}
\hline \multirow{2}{*}{ Index } & \multicolumn{4}{|c|}{ Count dates } \\
\hline & May 20 & May 30 & June 9 & June 13 \\
\hline \multicolumn{5}{|c|}{ winter watering } \\
\hline $\begin{array}{c}\text { number of } \\
\text { caterpillars } \\
\text { spec } / m^{2}\end{array}$ & 0,2 & 0,4 & 0,6 & 0,4 \\
\hline $\begin{array}{c}\text { damaged } \\
\text { plants, \% }\end{array}$ & 3,1 & 3,7 & 5,9 & 7,1 \\
\hline $\begin{array}{c}\text { destroyed } \\
\text { plants, \% }\end{array}$ & 0,0 & 2,0 & 1,8 & 2,0 \\
\hline \multicolumn{5}{|c|}{ Control figures } \\
\hline $\begin{array}{c}\text { number of } \\
\text { caterpillars } \\
\text { spec } / m^{2}\end{array}$ & 0,5 & 0,9 & 1,1 & 0,8 \\
\hline $\begin{array}{c}\text { damaged } \\
\text { plants, \% }\end{array}$ & 5,8 & 6,7 & 8,0 & 9,9 \\
\hline $\begin{array}{c}\text { destroyed } \\
\text { plants, \% }\end{array}$ & 0,0 & 5,5 & 3,3 & 3,5 \\
\hline
\end{tabular}

On the basis of our observations we can conclude that the character of the harm to sprouting cotton caused by cutworms may be different. They damage both new seedlings and those appeared on the surface of the soil, as well as young plants with $3-4$, sometimes even during 5-6 true cotton leaves. Germinating seeds that have not yet emerged on the surface of the soil ca also be damaged.

Caterpillar shoots that appear are either gnawed or overheated at soil level or slightly higher (at the root collar). Sometimes they strongly eat the cotyledon leaves or bite the growing point, which leads to the death of the plant. Sometimes the pest gnaws at the root collar, leaves and lower parts of fully matured plants with 5-6 true leaves. This occurs when hoeing clogged areas. In this case, weed vegetation is destroyed, and deprived of food caterpillars switch to cotton feeding.

Records and observations show that with a decrease in the number of weeds, damage to cotton seedlings by caterpillars of turnip moth (Agrotis segetum) increases (Table 3). 


\section{Table-3}

Influence of agrotechnical techniques on the number of turnip moth (Agrotis segetum) caterpillars and its damage to cotton seedlings of the farm of Jondor district of Bukhara region, 2019

\begin{tabular}{|c|c|c|c|c|}
\hline Indicators & $\begin{array}{l}\text { Control figure } \\
\text { (without } \\
\text { thinning of } \\
\text { cotton } \\
\text { seedlings) }\end{array}$ & $\begin{array}{l}\text { Thinning of } \\
\text { cotton } \\
\text { seedlings }\end{array}$ & $\begin{array}{c}\text { Cultivation with } \\
\text { mineral } \\
\text { fertilizers }\end{array}$ & $\begin{array}{c}\text { Cultivation and } \\
\text { hoeing with } \\
\text { sprout mandrel }\end{array}$ \\
\hline $\begin{array}{c}\text { Number of } \\
\text { cotton } \\
\text { seedlings, total, } \\
\text { pcs } / \mathrm{m}^{2}\end{array}$ & 16.6 & 17.2 & 16.6 & 16.2 \\
\hline $\begin{array}{c}\text { Damaged } \\
\text { pcs } / m^{2}\end{array}$ & 2.2 & 3.0 & 3.9 & 1.7 \\
\hline$\%$ & $1.3+1.3$ & $16.1+2.6$ & $23.7+1.9$ & $10.7+1.3$ \\
\hline $\begin{array}{c}\text { Number of } \\
\text { weeds } \\
\text { total, pcs } / \mathrm{m}^{2}\end{array}$ & 16.3 & 18.1 & 8.2 & $3 \cdot 3$ \\
\hline $\begin{array}{c}\text { including: black } \\
\text { nightshade }\end{array}$ & $7 \cdot 3$ & 3.5 & 2,3 & 0.6 \\
\hline field bindweed & 1.3 & 0.5 & 0.2 & 0.1 \\
\hline marie white & 5.9 & 3.6 & 2.1 & 0.3 \\
\hline $\begin{array}{c}\text { Number of } \\
\text { caterpillars, } \\
\text { pcs } / \mathrm{m}^{2}\end{array}$ & $1.95+0.32$ & $1.95+0.22$ & $1.42+0.19$ & $0.82+0.11$ \\
\hline
\end{tabular}

Note: Percentage of damage to seedlings increased due to filling them with soil during cultivation

In the fields where inter-row cultivation with mineral fertilizers was carried out in violation of agricultural cultivation and hoeing, damage to cotton by turnip moth (Agrotis segetum) increased, because a significant reduction of weeds' amount forced caterpillars to feed on the leaves and tender stems of cotton. In addition, hoeing with ketmen in many cases increases the number of damaged seedlings by covering them with soil.

Timely implementation of agrotechnical measures, thinning of seedlings, inter-row soil cultivation, and hoeing contributed to the better development of cotton and reduced the number of caterpillars of turnip moth (Agrotis segetum).

Growth, development and number of caterpillars largely depends on the duration of soil exploitation. So, on newly exploited light 
The American Journal of Agriculture and Boimedical Engineering (ISSN - 2689-1018)

Published: October 31, 2020 | Pages: 92-96

Doi: https://doi.org/10.37547/tajabe/Volumeo2Issue10-16

loamy and meadow-boggy soils, eggs and caterpillars of turnip moth (Agrotis segetum) are not found, although the fields are littered with black nightshade, field bindweed, white gauze, etc. (Table 4). It can be explained with the fact that the turnip moth has not yet accumulated in large quantities here.

\section{Table-4}

Influence of the duration of soil exploitation on the number of caterpillars of turnip moth (Agrotis segetum) in the farm in Jondor district of Bukhara region, 2019

\begin{tabular}{|c|c|c|c|c|c|c|c|}
\hline \multirow{2}{*}{$\begin{array}{l}\text { Date of } \\
\text { registration }\end{array}$} & \multicolumn{3}{|c|}{ Number of cotton plants } & \multicolumn{3}{|c|}{ Number of weeds, $p c s / m^{2}$} & \multirow{2}{*}{$\begin{array}{c}\text { number of } \\
\text { caterpillars, } \\
\text { pcs } / m^{2}\end{array}$} \\
\hline & $\begin{array}{c}\text { total } \\
p c s / m^{2}\end{array}$ & damag & $\mathrm{cs} / \mathrm{m}^{2}$ & $\begin{array}{c}\text { nightshade } \\
\text { black }\end{array}$ & $\begin{array}{c}\text { field } \\
\text { bindweed }\end{array}$ & $\begin{array}{l}\text { Mary } \\
\text { white }\end{array}$ & \\
\hline \multicolumn{8}{|c|}{ Newly-exploited lands } \\
\hline 04.05 & 14.0 & - & & -11 & 2 & 17 & - \\
\hline 18.05. & 14.5 & - & & -8 & - & 21 & - \\
\hline 26.05 & 15.0 & - & & -3 & 3 & 6 & - \\
\hline \multicolumn{8}{|c|}{ Long exploited lands } \\
\hline 04.05 & 16.0 & 2.7 & 6.8 & 17 & - & 22 & 1.4 \\
\hline 18.05 . & 16.7 & 1.6 & 1.5 & 46 & 5 & 23 & 1.8 \\
\hline 26.05 & 16.5 & 1.9 & 1.5 & 8 & 2 & 18 & 0.6 \\
\hline
\end{tabular}

\section{CONCLUSIONS}

Damage of cotton by turnip moth depends on the number of caterpillars, careful following to agrotechnical rules when growing cotton, as well as on the degree of covering cotton seedling with soil during cultivation, hoeing and thinning. If all these methods are followed, cotton damage is reduced by $19,5-54,9 \%$.

\section{REFERENCES}

1. Alkhasyants E.L., Komilov A.I. - "Preemergence weed control", "Cotton growing" No. 4. Moscow, 1972.
2. V.N. Chirkov. Workshop on plant growing. Tashkent. "Ukituvchi" PH, 1972.

3. F.M. Uspensky. What should be the system of integrated plant protection? Moscow, "Cotton growing" magazine, 1975, No. 2, pp. 25-30.

4. Tukhtaev Sh.Kh."Measures to prevent damage to cotton by turnip moth" Abstract. Tashkent, 1992.

5. Tukhtaev Sh.Kh. and others. "Study of the influence of different methods of applying herbicides on turnip moth (Agrotis segetum) and soil entomophages, Bukhara, 2018. 